\title{
Characterization investigations during mechanical alloying and sintering of $\mathrm{W}-20 \mathrm{vol} \% \mathrm{SiC}$ composites
}

\author{
Selim Coşkun a,*, M. Lütfi Öveçoğlu ${ }^{a}$, Burak Özkal ${ }^{a}$, Metin Tanoğlu ${ }^{b}$ \\ a Department of Metallurgy and Materials Engineering, Istanbul Technical University, ITU Ayazaga Kampusu Maslak, 34469 Maslak, Istanbul, Turkey \\ ${ }^{\mathrm{b}}$ Department of Mechanical Engineering, Izmir Institute of Technology, Gülbahçe, Izmir, Turkey
}

\section{A R T I C L E I N F O}

\section{Article history:}

Received 15 September 2008

Received in revised form

23 November 2009

Accepted 28 November 2009

Available online 3 December 2009

\section{Keywords:}

Composite materials

Mechanical alloying

Solid-state sintering

Microstructure

\begin{abstract}
A B S T R A C T
The effect of mechanical alloying and the sintering regime on the microstructural and the physical properties of $\mathrm{W}-\mathrm{SiC}$ composites were investigated. Powder mixtures of $\mathrm{W}-20 \mathrm{vol} . \%$ SiC were mechanically alloyed (MA'd) using a Spex mill for $3 \mathrm{~h}, 6 \mathrm{~h}$ and $24 \mathrm{~h}$. MA'd powders were characterized by Laser Diffraction Particle Size Analyzer, SEM and XRD investigations. MA'd W-20 vol.\% SiC powder composites were sintered under inert Ar and reducing $\mathrm{H}_{2}$ gas conditions at $1680^{\circ} \mathrm{C}$ and $1770^{\circ} \mathrm{C}$ for $1 \mathrm{~h}$. The microstructural and mechanical characterizations of the sintered samples were carried out by scanning electron microscope (SEM) and X-ray diffraction (XRD) and Vickers Hardness analyses. The addition of SiC remarkably increases the hardness of the composites. Hardness is also increased with decreasing grain size and increasing amount of MA.
\end{abstract}

(c) 2009 Elsevier B.V. All rights reserved.

\section{Introduction}

Many of the modern technologies require materials with unusual combinations of properties which cannot be met by conventional metal alloys, ceramics, and polymeric materials. Since no single material could fulfill these rising requirements in the last 20 years, an increasing interest in developing new materials has been aroused to serve the need for new materials having unique properties for special applications [1,2]. Therefore, in parallel with the development of composite materials, such material combinations which fulfill the requirements of the modern technology have been, and are yet being, extended. Composite materials are especially attractive for applications in marine, automotive, aviation and aerospace industries because of their exceptional strength and stiffness-to-density ratios and superior physical properties. As a result, using composite materials in these industries has led to improvements in the technology [3].

Among different types of composites, particle-reinforced composites provide cost-effectiveness and especially isotropic properties to the composite and can be processed using similar technology used for monolithic materials [4]. Furthermore, MMC'S with discontinuous reinforcements are also attractive for their processability into various shapes [5].

\footnotetext{
* Corresponding author. Tel.: +90 2122853393; fax: +90 2122853427.

E-mail address: coskunsel@itu.edu.tr(S. Coşkun).
}

As interesting and appropriate matrix materials with their high melting point, high modulus, high resistance of thermal shock, low CTE and good high temperature strength and stiffness, in this last decade, tungsten and its alloys have received attention with a view of improving the high temperature mechanical properties [6]. As dispersion strengtheners, refractory carbide, nitride and oxide phases, such as TiC, $\mathrm{ZrC}, \mathrm{HfC}$, TiN, $\mathrm{Y}_{2} \mathrm{O}_{3}, \mathrm{La}_{2} \mathrm{O}_{3}, \mathrm{Sm}_{2} \mathrm{O}_{3}, \mathrm{ThO}_{2}, \mathrm{ZrO}_{2}$, etc. have been mainly used to improve the mechanical properties of tungsten and its alloys [6,1,7]. However, their content in tungsten is usually less than 2 vol.\% and to date [7], unfortunately, research on tungsten matrix composites reinforced with a higher content of ceramic phase has not been reported. Furthermore, there is no literature which reports on tungsten matrix composites reinforced with $\mathrm{SiC}$ which is a hard and strong material with low density [8].

Among the various non-oxide ceramics that have found commercial applications, $\mathrm{SiC}$ is the best one. Attractive properties, such as good specific strength and Young modulus as a function of temperature, the specific stiffness, corrosion and erosion resistance have made $\mathrm{SiC}$ an attractive alternative to the hard metal compositions [8-10]. Furthermore, it is an important ceramic used in structural applications, such as automotive engines, cutting tools, heat exchange and mechanical seals $[8,10,11]$.

Mechanical alloying (MA) is an advanced fabrication process by means of which ultra-fine and homogenous composite powders can be produced [12]. Even, nanocrystalline materials (with a grain size of few nanometers, usually $<100 \mathrm{~nm}$ ) are also produced by MA of powder mixtures [13]. Additionally, it has been recognized that 


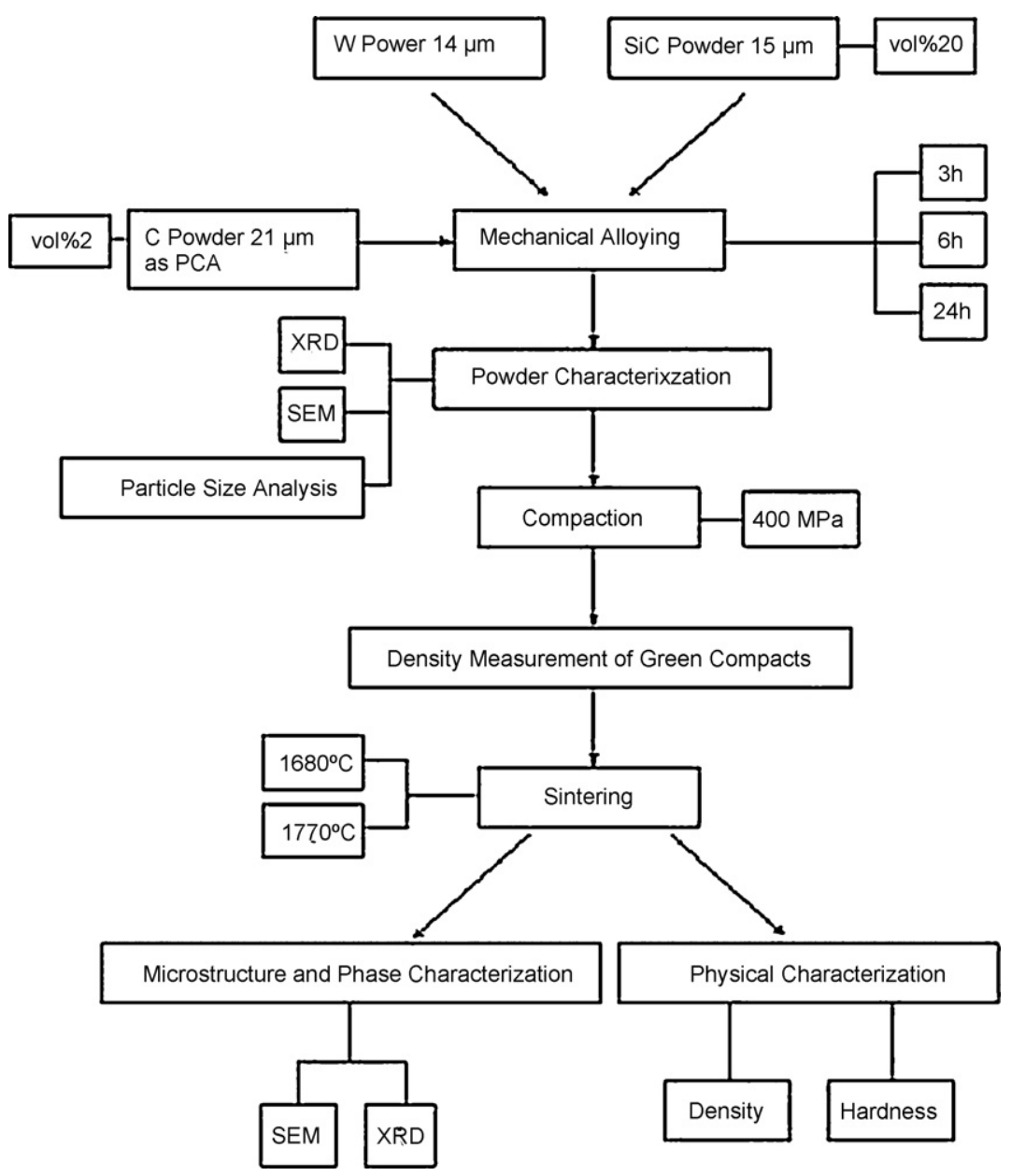

Fig. 1. The flowchart of the experimental procedure.

by using this technique chemical (displacement) reactions in powder mixtures can be induced at room temperature or at much lower temperatures than normally required to synthesize pure metals $[13,14]$. The structure and constitution of advanced materials can be better controlled by processing them under non-equilibrium (or far-from-equilibrium) conditions and MA is such a processing method that materials can be produced under non-equilibrium conditions [15]. MA can be defined as a powder metallurgy process for producing composite metal powders with a controlled fine microstructure by repeated cold welding, fracturing and rewelding of powder particles in a high-energy ball mill $[13,16,17]$.

Keeping the above concepts in mind, the aim of this study has been to develop and characterize nanostructured SiC particlereinforced tungsten composite powders and their consolidated and sintered counterparts. Composite powders with W-20 vol.\% SiC composition were first investigated using SEM and XRD techniques and then mechanically alloyed in different time intervals. As-MA'd powders were consolidated using a uniaxial press and sintered under $\mathrm{H}_{2}$ atmosphere. Bulk density and microhardness tests were carried out on sintered W-20 vol.\% SiC samples.

\section{Experimental procedure}

Elemental tungsten (W) powders (99.9\% purity, $14 \mu \mathrm{m}$ average particle size) as the matrix of the composite and silicon carbide $(\mathrm{SiC})$ powders (99.9\% purity, $15 \mu \mathrm{m}$ average particle size) as reinforcement were mixed to form powder batches to constitute the composition $\mathrm{W}-20 \mathrm{vol} . \% \mathrm{SiC}$ (hereafter referred to as W20SiC). Furthermore, graphite powders (99.9\% purity, $21 \mu \mathrm{m}$ average particle size) was used as a process control agent (PCA) to minimize cold welding between powder particles and thereby to inhibit agglomeration.
Mechanical alloying experiments were carried out for $3 \mathrm{~h}, 6 \mathrm{~h}$ and $24 \mathrm{~h}$ in a tungsten carbide (WC) vial using a $8000 \mathrm{D}^{\mathrm{TM}}$ Spex mill with a speed of $1200 \mathrm{rpm}$. WC balls with a diameter of $6.35 \mathrm{~mm}(1 / 4 \mathrm{in}$.) were used as milling media. The ball-to-powder weight ratio (BPR) was 10:1.

Powder particle size measurements were carried out in a Malvern ${ }^{\mathrm{TM}}$ Mastersizer Laser particle size analyzer. Microstructural characterization investigations of as-blended and MA'd powders were conducted using a Jeol ${ }^{\mathrm{TM}}$-JSM-T330 scanning electron microscope (SEM), a Jeol ${ }^{\mathrm{TM}}$-JSM-7000F field emission scanning electron microscope (SEM-FEG) and a Bruker ${ }^{\mathrm{TM}}$ X-Ray Diffractometer (XRD) (Cu K $\mathrm{K}_{\alpha}$ radiation). Powder consolidation was carried out in a 10 ton capacity "APEX ${ }^{\mathrm{TM}}$ 3010/4" one-action hydraulic press to obtain cylinder type compacts of MA'd W2OSiC composites with a diameter of $12 \mathrm{~mm}$ under a uniaxial pressure of $400 \mathrm{MPa}$. As-blended

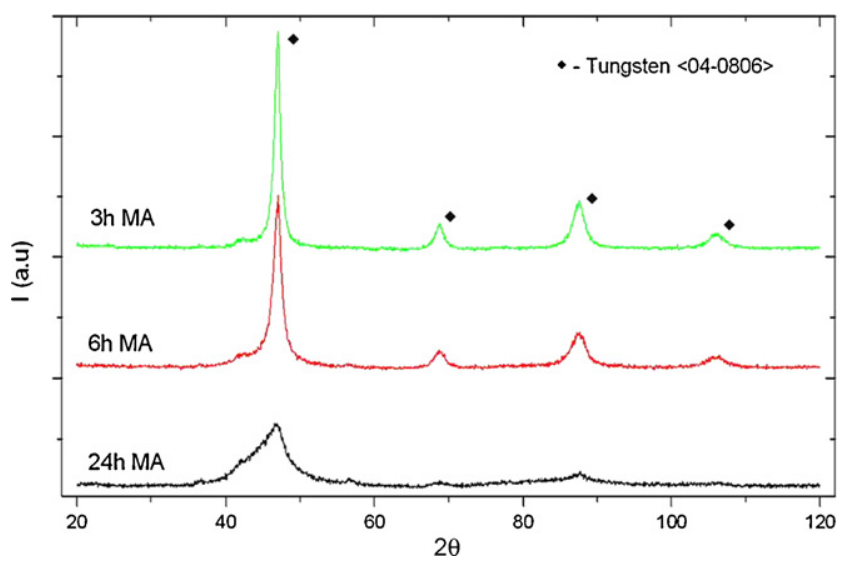

Fig. 2. XRD patterns of MA'd W2OSiC samples. 


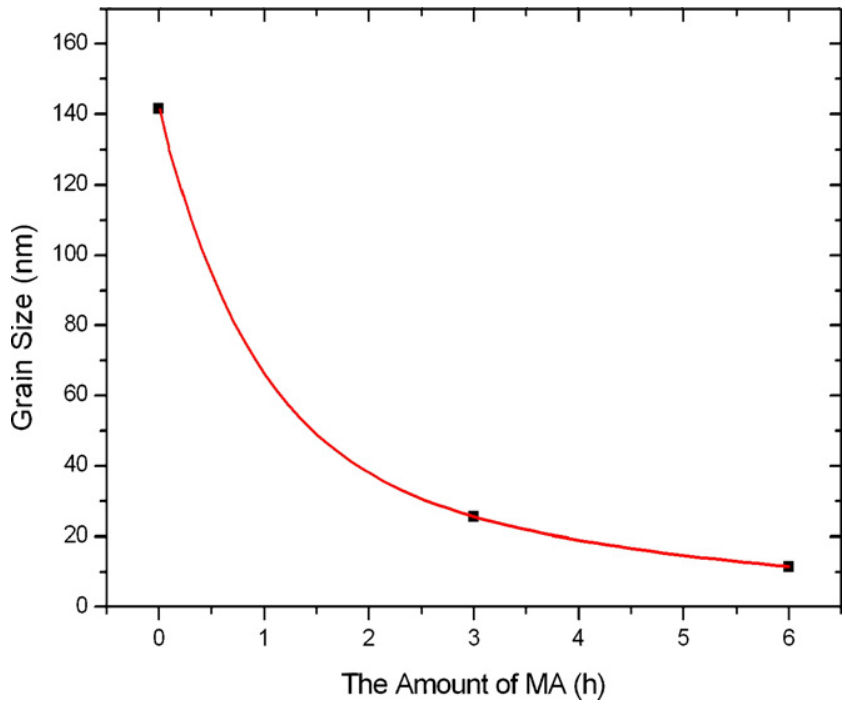

Fig. 3. Evolution of the grain size as a function of the milling time.

powders could not be compacted using these conditions and for this reason there are no pressed and sintered compacts prepared from as-blended powders used in this study. Green densities of the samples were measured dimensionally. The compacts were sintered in an Anter ${ }^{\mathrm{TM}}$ Dilatometer at $1680^{\circ} \mathrm{C}(1953 \mathrm{~K})$ and/or in a $1800 \mathrm{M}$ Vac Graphite Linn ${ }^{\mathrm{TM}}$ gas sintering furnace at $1770^{\circ} \mathrm{C}(2043 \mathrm{~K})$ under both inert $\mathrm{Ar}$ and reducing $\mathrm{H}_{2}$ gas flowing conditions for $1 \mathrm{~h}$. Microstructural characterizations of sintered W20SiC samples were carried out using the same XRD and SEM equipment as those used for MA'd W20SiC powders. Because this study generated very small samples, mechanical behavior was only probed by Vickers microhardness measurements which were conducted on the sintered samples using a Shimadzu ${ }^{\mathrm{TM}}$ microhardness tester under a load of $100 \mathrm{~g}$ for $15 \mathrm{~s}$. Results of hardness tests were averaged out of 25 successive indentations. Sintered densities were measured by using the Archimedes method.

A Bruker ${ }^{\mathrm{TM}}$ D8 X-Ray Diffractometer was used to monitor the changes in the ballmilled powder. The crystallite size was estimated using the modified Scherrer's [18]
Table 1

Weight and atomic percentages of the elements present in (a) equiaxed particles, (b) sharp-edged particles and (c) flat-like particles.

\begin{tabular}{lrr}
\hline Element & Weight\% & Atomic\% \\
\hline (a) & & \\
C & 0.25 & 3.68 \\
Si & 0.00 & 0.00 \\
W & 99.75 & 96.32 \\
(b) & & \\
C & 20.32 & 49.12 \\
Si & 43.72 & 45.20 \\
W & 35.96 & 5.68 \\
(c) & & \\
C & 70.75 & 97.37 \\
Si & 0.00 & 0.00 \\
W & 29.25 & 2.63 \\
\hline
\end{tabular}

formula based on the broadening of XRD diffraction peaks:

$B_{r}=\frac{k \lambda}{L \cos \theta}+\eta \tan \theta$

where $B_{r}$ is the total broadening due to reduction in crystallite size and lattice strains, $\lambda$ the X-ray wavelength, $L$ the crystallite size, $\eta$ the strain in the material, $k$ a constant and $\theta$ is the diffraction angle.

The experimental procedure for the present investigation is given in the flow chart in Fig. 1.

\section{Results and discussion}

\subsection{Characterization of powders}

\subsubsection{Microstructural characterization}

XRD diffraction patterns of mechanically alloyed W20SiC powders are shown in Fig. 2. As seen in Fig. 2, only the peaks of $W$ which has a BCC Bravais lattice and $\operatorname{Im} 3 \mathrm{~m}$ space group with the lattice parameter of $a=0.316 \mathrm{~nm}$ [19] can be identified; peaks for $\mathrm{SiC}$ are not seen, probably due to the small amount $(1.5 \mathrm{wt} \%)$ in (a)

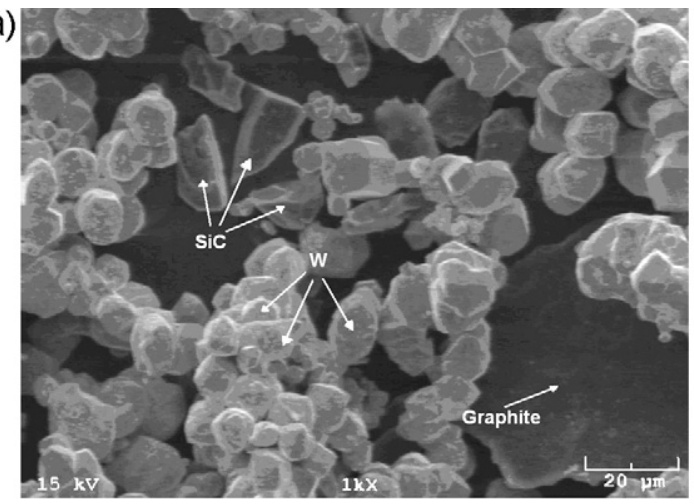

(c)

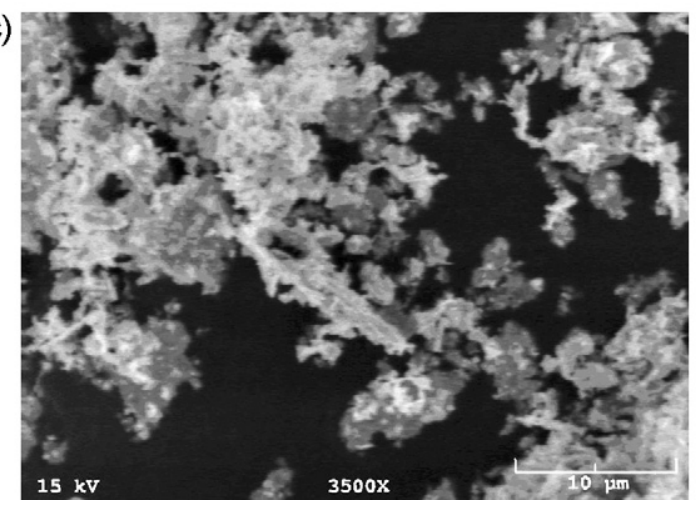

(b)

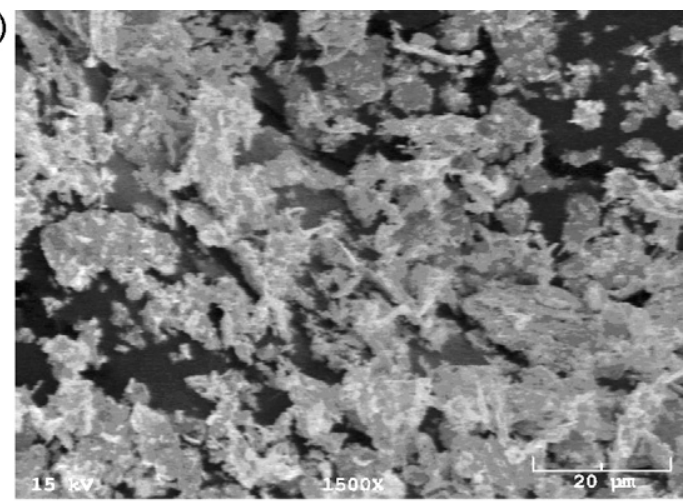

(d)

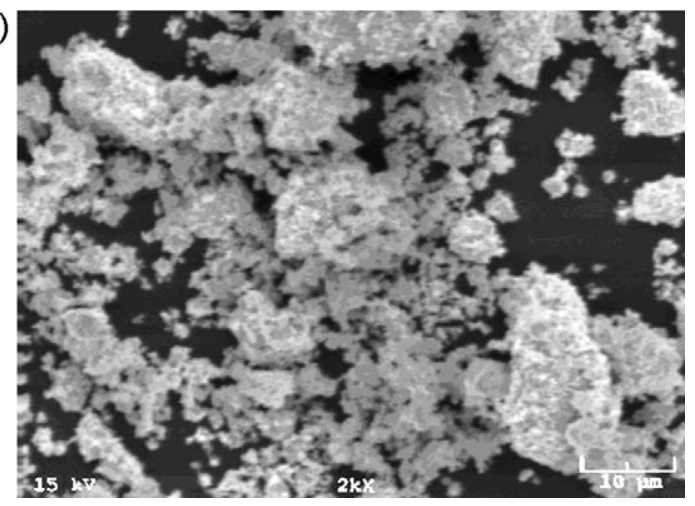

Fig. 4. SEM images of W2OSiC powders (a) in the as-blended condition and after mechanical alloying for (b) $3 \mathrm{~h}$, (c) $6 \mathrm{~h}$, (d) $24 \mathrm{~h}$. 
the powder blend. Further, it is also clear that with increasing MA, peaks are broadened and peak heights are decreased, as a result of grain refinement and an increase in internal strain due to mechanical alloying. The dependence of grain size on mechanical alloying duration is shown in Fig. 3. As seen in Fig. 3, the average grain shows a rapid decrease to about $26 \mathrm{~nm}$ after MA'ing for $3 \mathrm{~h}$ and it is about $12 \mathrm{~nm}$ after MA for $6 \mathrm{~h}$. The grain size of the W20SiC powder MA'd for $24 \mathrm{~h}$ could not be estimated from the modified Scherrer's [18] equation since all the peaks except the one belonging to (1 10 ) plane disappeared due to broadening.

Fig. 4a-d shows a series of SEM micrographs taken from as-blended W20SiC powders and from those MA'd for $3 \mathrm{~h}, 6 \mathrm{~h}$ and (a)

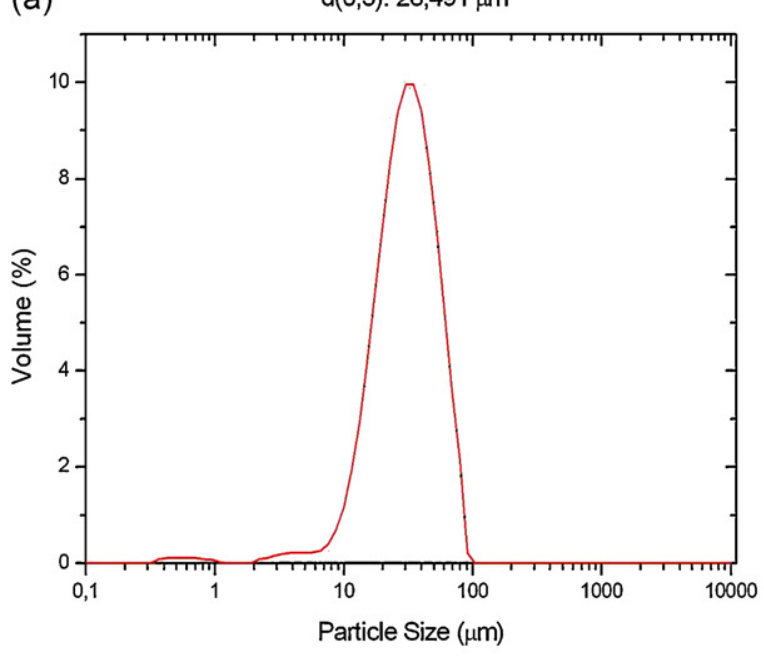

(c)

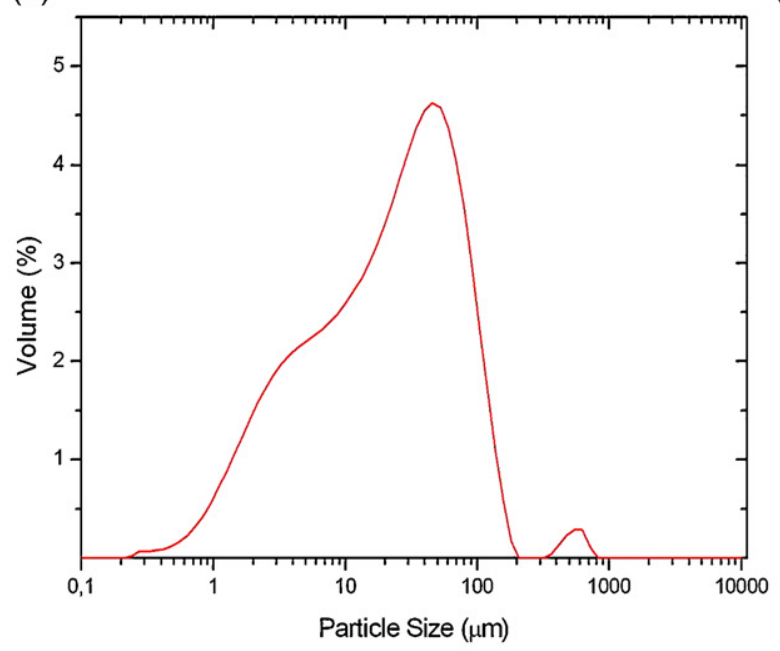

(e)

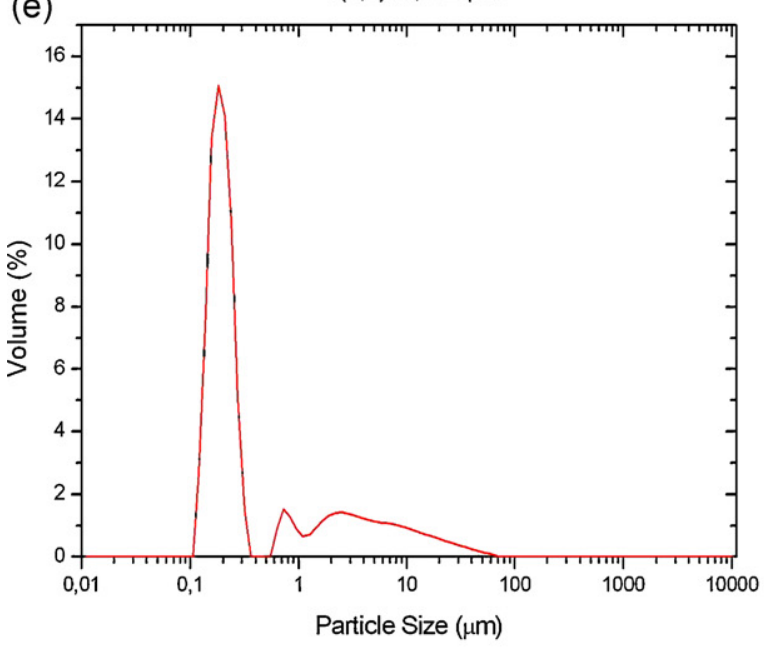

(b)

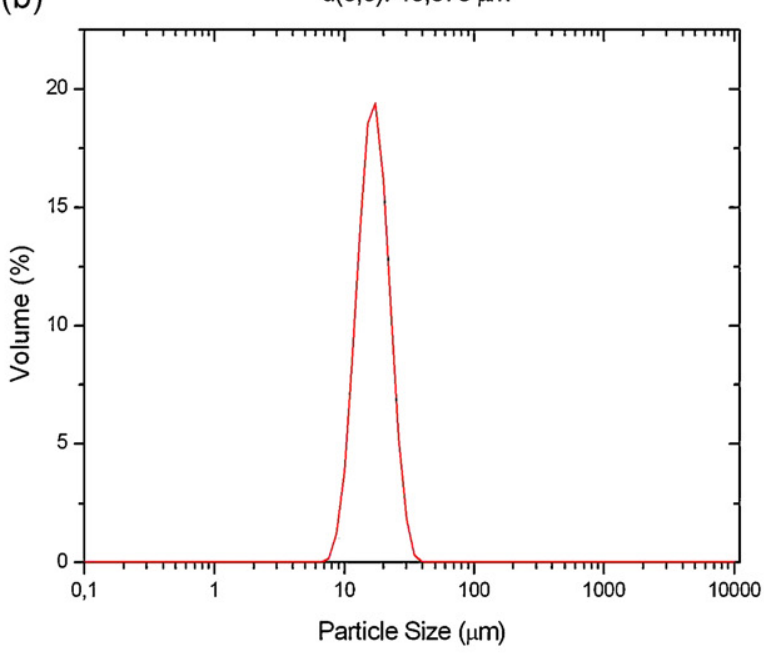

(d)

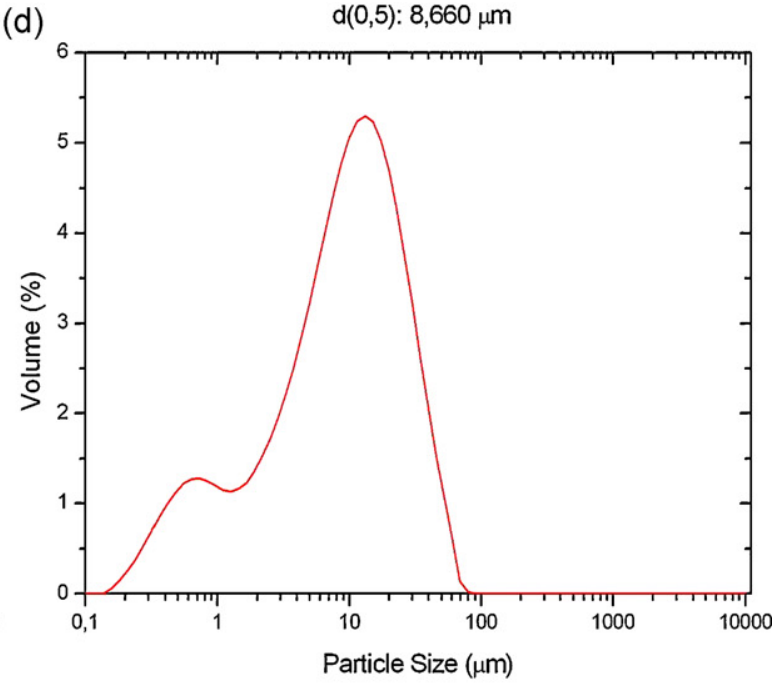

(f)

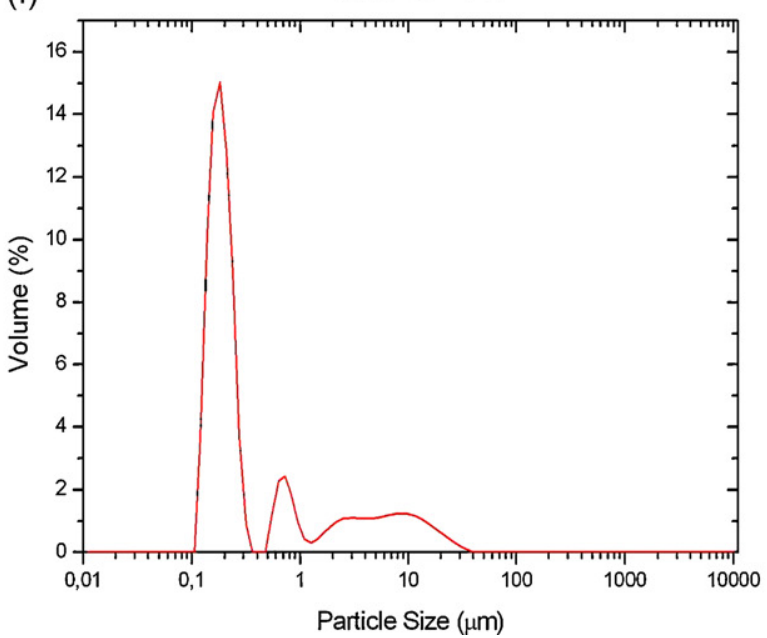

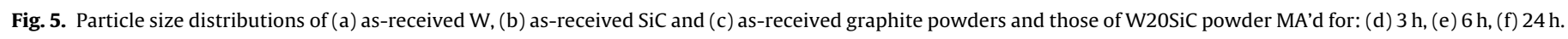



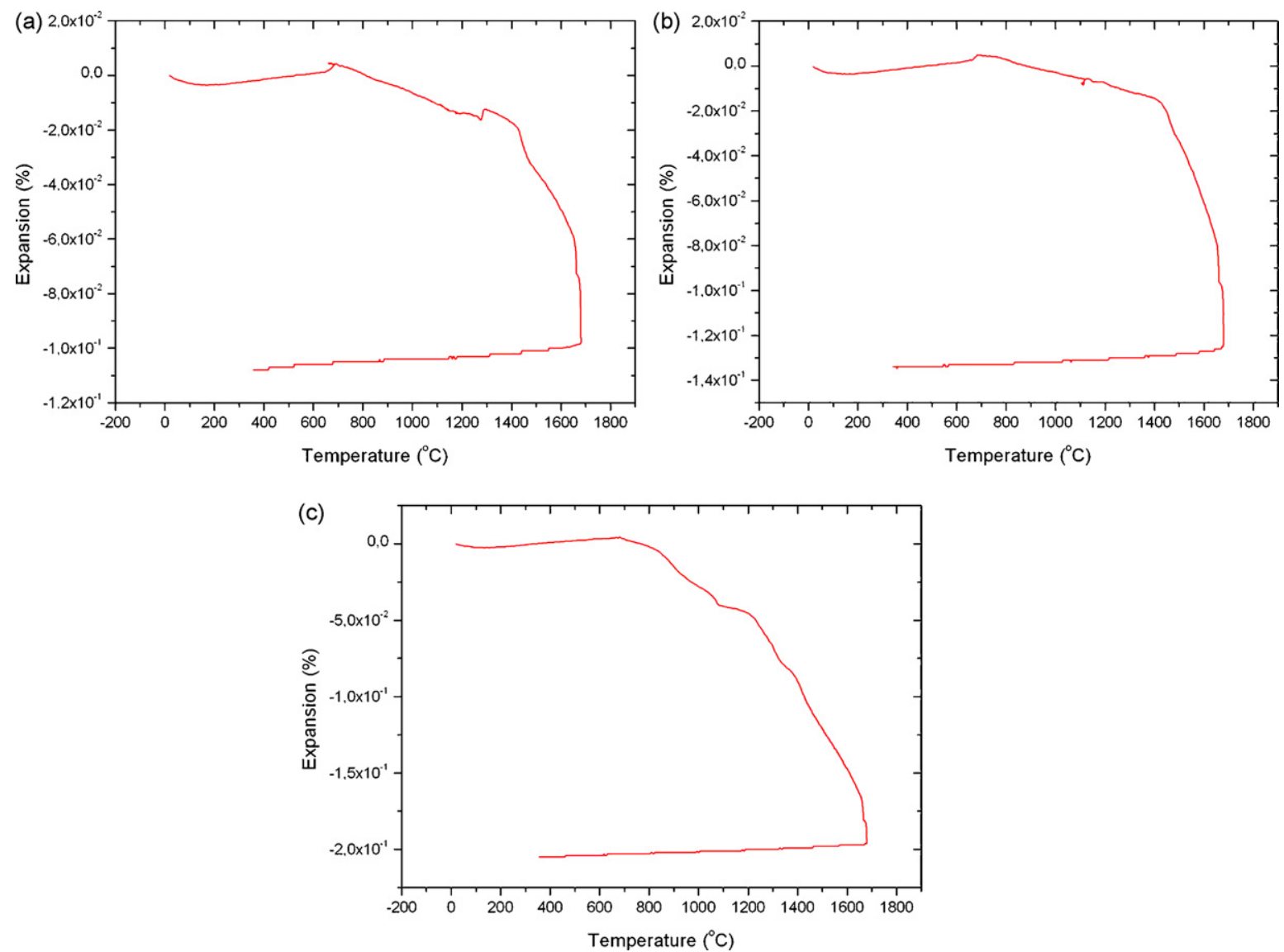

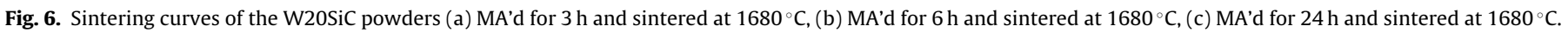

$24 \mathrm{~h}$, respectively. It is clear from Fig. 4 that powder particle sizes decrease with increasing milling time. EDS measurements (Table 1) taken from different shaped particles seen in Fig. 4a revealed that round and nearly equiaxed particles are $\mathrm{W}$ particles, sharp-edged particles at the left-top of the image are $\mathrm{SiC}$ particles and the flake-like particle at the right-bottom of the image is graphite.

Similar to the $\mathrm{W}-\mathrm{SiC}$ system of the present study, alloying has been reported to occur in brittle-brittle component systems such as $\mathrm{Si}-\mathrm{Ge}$ and $\mathrm{Mn}-\mathrm{Bi}$ or $\mathrm{Fe}_{2} \mathrm{O}_{3}-\mathrm{Cr}_{2} \mathrm{O}_{3}$ and $\mathrm{ZrO}_{2}-\mathrm{Y}_{2} \mathrm{O}_{3}$ [14,15]. During MA of brittle-brittle component systems, it has been observed that the harder (more brittle) component gets fragmented and gets embedded in the softer (less brittle) component [14]. With continued milling, the more brittle particles get uniformly dispersed, if they are insoluble, in the less brittle matrix $[14,16]$. It can be clearly seen that in the initial stages of milling the less brittle metal (here $\mathrm{W}$ ) powder particles get flattened by the ball-powder-ball collisions, while the brittle $\mathrm{SiC}$ particles get fragmented as expected [14] (Fig. 4b). With continuing milling, these flattened particles get fragmented [14] (Fig. 4c) and finally composite powder particles are formed with compositions similar to starting powder batch composition [14] (Fig. 4d).

Fig. 5a-f shows the particle size distributions of as-received $\mathrm{W}$, $\mathrm{SiC}$, graphite powder and those MA'd for $3 \mathrm{~h}, 6 \mathrm{~h}$ and $24 \mathrm{~h}$, respectively. According to these analyses, the median particle size of as-received W powders is less than $28 \mu \mathrm{m}$ (Fig. 5a), that of SiC powders is less than $14 \mu \mathrm{m}$ (Fig. $5 \mathrm{~b}$ ) and that of graphite powders is less than $21 \mu \mathrm{m}$ (Fig. 5c). Median particle sizes are about $8.66 \mu \mathrm{m}$, $0.202 \mu \mathrm{m}$ and $0.195 \mu \mathrm{m}$ for the W20SiC powders MA'd for $3 \mathrm{~h}, 6 \mathrm{~h}$ and $24 \mathrm{~h}$, respectively. With increasing MA, specific surface area of the powders drastically increases, which are less than $1 \mathrm{~m}^{2} / \mathrm{g}$ for as-blended W20SiC powders, $2.45 \mathrm{~m}^{2} / \mathrm{g}$ for those MA'd for $3 \mathrm{~h}$,
$25.4 \mathrm{~m}^{2} / \mathrm{g}$ MA'd for $6 \mathrm{~h}$ and $26.2 \mathrm{~m}^{2} / \mathrm{g}$ MA'd for $24 \mathrm{~h}$. It is clear from the results that the average particle sizes $(\sim 200 \mathrm{~nm})$ and specific areas barely change between $6 \mathrm{~h}$ and $24 \mathrm{~h}$ MA times.

\subsection{Characterization of as-consolidated and sintered samples}

\subsubsection{Determination of the sintering regime}

Several factors influence the sintering regimes, including time, temperature, particle size, atmosphere, compacted density, particle size distribution, etc. [20]. For tungsten powders with an average size of $4 \mu \mathrm{m}$, typical sintering temperatures up to $3000^{\circ} \mathrm{C}$ and times between $15 \mathrm{~min}$ and $30 \mathrm{~min}$ required to achieve high densities [21]. For the same powder, sintering times vary between $1 \mathrm{~h}$ and $2 \mathrm{~h}$ at $2400^{\circ} \mathrm{C}$ and longer times $(40-110 \mathrm{~h}$ ) are required at lower temperature range between $1775^{\circ} \mathrm{C}$ and $1825^{\circ} \mathrm{C}[20,21]$. However, both sintering temperatures and times can be decreased by decreasing the particle size of powders [20].

Taking these facts into account, the sintering regime is mainly determined by several additional experiments using a dilatometer, in which different flow rates and flow durations were applied. Fig. 6a-c shows the dilatometer curves (\% expansion vs. temperature) of as-consolidated W20SiC pellets sintered at $1680^{\circ} \mathrm{C} \mathrm{MA}$ 'd for $3 \mathrm{~h}, 6 \mathrm{~h}$ and $24 \mathrm{~h}$, respectively. As can be seen in Fig. $6 \mathrm{a}-\mathrm{c}$, sintering behaviors of all pellets were similar. Furthermore, it was observed that the initial reducing effect of $\mathrm{H}_{2}$ began approximately for all at the same temperatures $\left(\sim 680^{\circ} \mathrm{C}\right)$, even though its flow had started earlier. Moreover, this initial effect slowed down again at approximately the same temperatures $\left(\sim 1000^{\circ} \mathrm{C}\right)$, even though the $\mathrm{H}_{2}$ flow was continuing. According to these curves, samples MA'd for $3 \mathrm{~h}, 6 \mathrm{~h}$ and $24 \mathrm{~h}$ have shrinkage values of $10.8 \%, 13.4 \%$ and $20.5 \%$, respectively. 

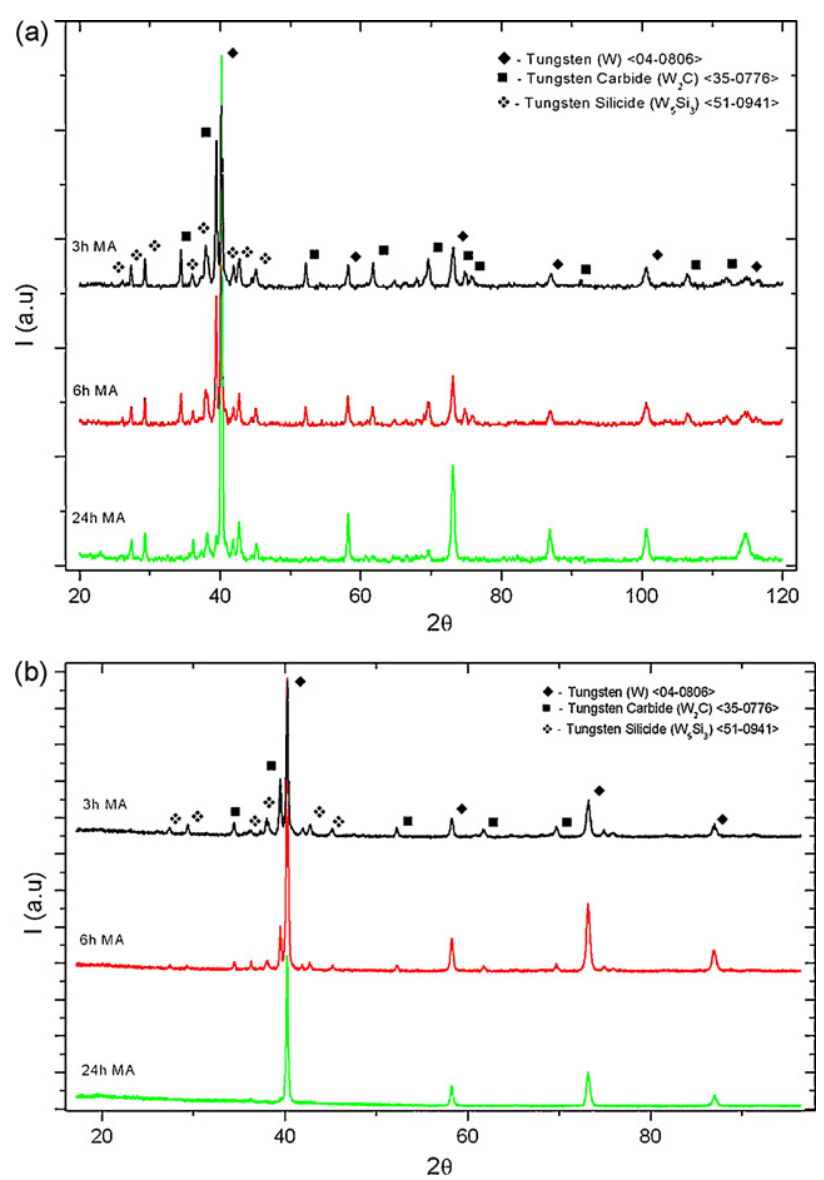

Fig. 7. (a) XRD patterns of W20SiC samples sintered at $1680^{\circ} \mathrm{C}$ and MA'd for $3 \mathrm{~h}, 6 \mathrm{~h}$ and $24 \mathrm{~h}$, (b) XRD patterns of W20SiC samples sintered at $1770^{\circ} \mathrm{C}$ and MA'd for $3 \mathrm{~h}$, $6 \mathrm{~h}$ and $24 \mathrm{~h}$.

Sintering at $1680^{\circ} \mathrm{C}$ was chosen as conventional sintering which is to heat the powder compact at a certain rate, followed by holding it at the highest temperature until the maximum density is reached. However, a second sintering regime is different which uses two steps in the heating schedule. The sample is first heated to a higher temperature $\left(1770^{\circ} \mathrm{C}\right)$ to achieve an intermediate density, then cooled down and held at a lower temperature $\left(1600^{\circ} \mathrm{C}\right)$. By means of the second sintering regime, the grain growth was tried to be inhibited. The characteristics of this regime are explained elsewhere [22,23]. Due to the fact that the dilatometer has a maximum operation temperature of $1700^{\circ} \mathrm{C}$, second sintering regime was applied in Linn ${ }^{\mathrm{TM}}$ gas sintering furnace and sintering curves in Fig. 6a-c were extrapolated to $1770^{\circ} \mathrm{C}$.

\subsubsection{Microstructural evolution during sintering}

Fig. 7a and b shows XRD patterns showing the effect of MA times taken from W20SiC samples sintered at $1680^{\circ} \mathrm{C}$ and $1770^{\circ} \mathrm{C}$, respectively. As clearly seen in Fig. 7, phase compositions of the MA'd samples were changed as a result of the reactions during sintering process. $\mathrm{W}_{2} \mathrm{C}$ phase is identified in the samples MA'd for $3 \mathrm{~h}$ and $6 \mathrm{~h}$ at $1680^{\circ} \mathrm{C}$, which has a simple hexagonal Bravais lattice and $P \overline{3} \mathrm{ml}$ space group with lattice parameters of $a=0.299 \mathrm{~nm}$ and $b=0.473 \mathrm{~nm}$ [24]. In addition, there are also some tungsten silicide phases $\left(\mathrm{W}_{5} \mathrm{Si}_{3}\right.$ and $\left.\mathrm{WSi}_{2}\right)$ identified, but it is somewhat difficult to identify the exact tungsten silicide phase since $d$-spacing values for these silicides are too close to each other. However, $\mathrm{W}_{5} \mathrm{Si}_{3}$ phase, which has a body-centered tetragonal Bravais lattice and $14 / \mathrm{mcm}$ space group with lattice parameters $a=0.961 \mathrm{~nm}$ and $b=0.496 \mathrm{~nm}$ [25] seems more likely to be stable in accordance with the observation of Seng and Barnes [26] who expressed that $\mathrm{W}_{5} \mathrm{Si}_{3}$ is the most stable phase in the $\mathrm{W}-\mathrm{SiC}$ system. Moreover, these results are consistent with the study of Baud et al. [27], where they detected $\mathrm{W}, \mathrm{W}_{2} \mathrm{C}$ and $\mathrm{W}_{5} \mathrm{Si}_{3}$ in the $\mathrm{SiC} / \mathrm{W}$ samples annealed above $1100^{\circ} \mathrm{C}$. Similarly, Son et al. reported the formation of $\mathrm{W}_{2} \mathrm{C}, \mathrm{W}_{5} \mathrm{Si}_{3}$ and $\mathrm{WC}$ after hot-pressing $\mathrm{W}$ and $\mathrm{SiC}$ powders at $1700-1900^{\circ} \mathrm{C}$ [28]. Also, Goesmann and Fetzer [29,30] showed that $\mathrm{W}_{2} \mathrm{C}$ and $\mathrm{W}_{5} \mathrm{Si}_{3}$ were stable phases above $1200^{\circ} \mathrm{C}$ and $1500^{\circ} \mathrm{C}$ in $\mathrm{W}-\mathrm{SiC}$ system, respectively. With increasing mechanical alloying, the intensities of $\mathrm{W}_{2} \mathrm{C}$ diffraction patterns decrease and the intensities of $\mathrm{W}_{5} \mathrm{Si}_{3}$ peaks increase. For the W20SiC samples MA'd for $24 \mathrm{~h}$ and sintered at $1680^{\circ} \mathrm{C}$ (Fig. 7a) only $\mathrm{W}$ and $\mathrm{W}_{5} \mathrm{Si}_{3}$ phases can be identified inferring that all the $\mathrm{SiC}$ was consumed to form $\mathrm{W}_{5} \mathrm{Si}_{3}$ and free carbon in the structure escaped out as some $\mathrm{C}_{x} \mathrm{H}_{y}$ or $\mathrm{CO}_{x}$ gas. Weight loss of this sample (5\%) was more than other samples, which supported this observation.

Thus, on the basis of Fig. 7a, it can be deduced that a chemical reaction between $\mathrm{W}_{2} \mathrm{C}$ and $\mathrm{SiC}$, and between $\mathrm{SiC}$ and $\mathrm{W}$ occurred at low sintering temperatures $\left(1680^{\circ} \mathrm{C}\right)$. Pertinent to this observation, it is appropriate here to list possible reactions, which Seng and Barnes [26] expressed as:

$$
\begin{aligned}
& \mathrm{SiC}+8 / 3 \mathrm{~W}_{2} \mathrm{C} \rightarrow 1 / 3 \mathrm{~W}_{5} \mathrm{Si}_{3}+11 / 3 \mathrm{WC} \\
& \mathrm{SiC}+8 / 3 \mathrm{~W} \rightarrow 1 / 3 \mathrm{~W}_{5} \mathrm{Si}_{3}+\mathrm{WC}
\end{aligned}
$$

It is likely that the reaction product WC has reacted with $\mathrm{W}$ to form the $W_{2} C$ present in the sintered W20SiC samples MA'd for $3 \mathrm{~h}$ and $6 \mathrm{~h}$ (Fig. 7a). On the other hand, $\mathrm{W}_{2} \mathrm{C}$ is not detected for the sintered W20SiC sample MA'd for $24 \mathrm{~h}$. The reason for this is not clearly understood.

Considering W20SiC samples sintered using second sintering regime (Fig. $7 \mathrm{~b}$ ), all possible phases $\left(\mathrm{W}, \mathrm{W}_{2} \mathrm{C}\right.$ and $\left.\mathrm{W}_{5} \mathrm{Si}_{3}\right)$ are present in the sample MA'd for $3 \mathrm{~h}$, but XRD peak intensities decrease in the sample MA'd for $6 \mathrm{~h}$. In the sample MA'd for $24 \mathrm{~h}$ all the peaks except those of $\mathrm{W}$ disappeared. This is believed to be due to recrystallization triggered by severe plastic deformation induced during mechanical alloying. As a result, new strain free grains of W and SiC might have been formed.

SEM images of W20SiC samples sintered using second sintering regime are shown in Fig. 8a-c. SEM images comprise areas with varying contrasts. On the basis of EDS measurements taken from different areas, dull white areas consist of $\mathrm{W}$ and the darker, mottled white areas consist of $\mathrm{W}$ and $\mathrm{W}_{2} \mathrm{C}$ phases. In addition, grey areas consist of the silicide phases (Fig. 8a and b) and spherical shaped black areas are mainly pores. Whereas both $\mathrm{W}$ grains and $\mathrm{W}+\mathrm{W}_{2} \mathrm{C}$ regions have polygonal shapes, $\mathrm{W}_{5} \mathrm{Si}_{3}$ grains are finer but similar in shape. Further, comparing Fig. $8 \mathrm{a}-\mathrm{c}$ with each other, it can be observed that MA has a definite effect on the evolution of the sintered microstructure resulting in the enlargement of all phases ( $W$, $\mathrm{W}_{2} \mathrm{C}$, and $\mathrm{W}_{5} \mathrm{Si}_{3}$ ) with MA duration. Although the microstructures and shapes of the seen in Fig. $8 \mathrm{a}$ and $\mathrm{b}$ are similar, the size ranges of $\mathrm{W}$ and $\mathrm{W}_{5} \mathrm{Si}_{3}$ grains increase from $0.5 \mu \mathrm{m}$ to $2 \mu \mathrm{m}$ and $0.5 \mu \mathrm{m}$ to $2.5 \mu \mathrm{m}$ for the $3 \mathrm{~h}$ MA'd sample to $1 \mu \mathrm{m}$ to $3 \mu \mathrm{m}$ and $1 \mu \mathrm{m}$ to $4 \mu \mathrm{m}$ for the $6 \mathrm{~h}$ MA'd sample, respectively. Similarly, $\mathrm{W}+\mathrm{W}_{2} \mathrm{C}$ regions are grown from a size range of $1-4 \mu \mathrm{m}$ for the $3 \mathrm{~h}$ MA'd sample (Fig. 8a) to about 2-5 $\mu \mathrm{m}$ for the $6 \mathrm{~h}$ MA'd sample (Fig. 8b). Pores are mostly smaller than $0.5 \mu \mathrm{m}$ in the W20SiC sample MA'd for $3 \mathrm{~h}$ (Fig. 8a) and are between $0.5 \mu \mathrm{m}$ and $1 \mu \mathrm{m}$ in size in the sample MA'd for $6 \mathrm{~h}$ (Fig. 8b). As seen in Fig. 8c, the microstructure of the sintered W20SiC sample MA'd for $24 \mathrm{~h}$ comprise only W grains and contain large voids and thus is different from those of the MA'd $3 \mathrm{~h}$ and MA'd $6 \mathrm{~h}$ samples. The presence of only W phase in the $24 \mathrm{~h}$ MA'd sample also confirms the XRD scan given in Fig. 7b.

Considering the $\mathrm{W} 20 \mathrm{SiC}$ samples sintered at $1680^{\circ} \mathrm{C}$, the one MA'd for $3 \mathrm{~h}$ (Fig. 9a) consists of very small grains, but also contains a large number of pores and cracks due to the presence of 
(a)

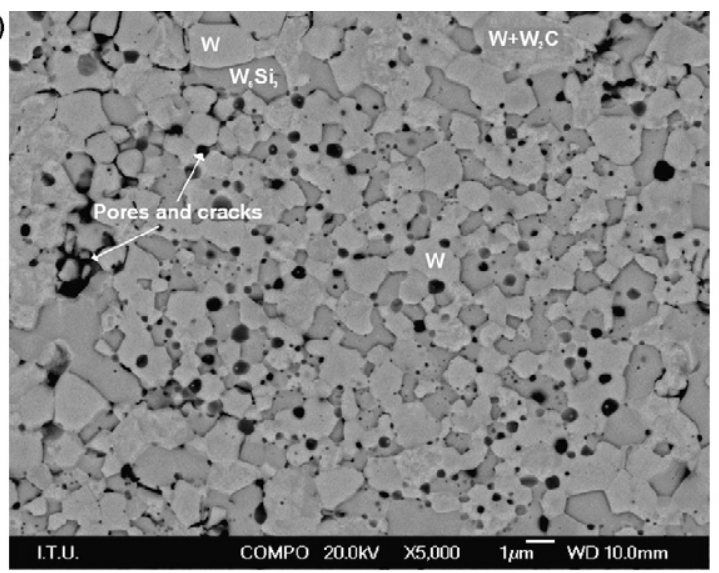

(b)

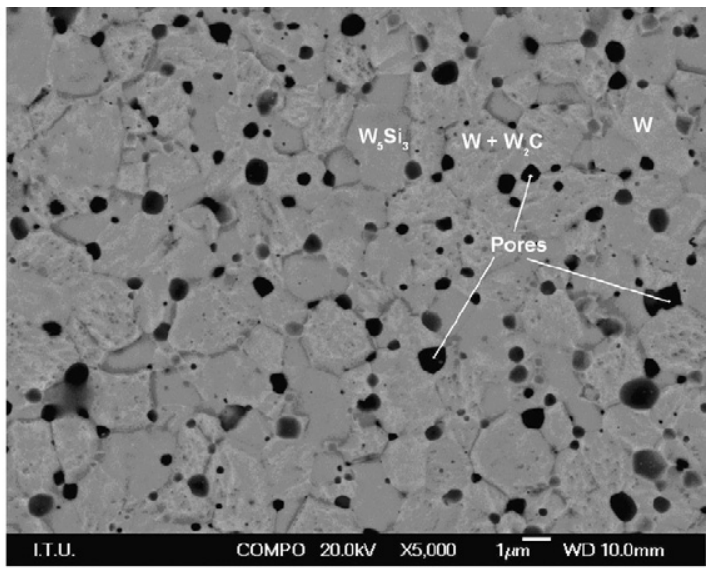

(c)

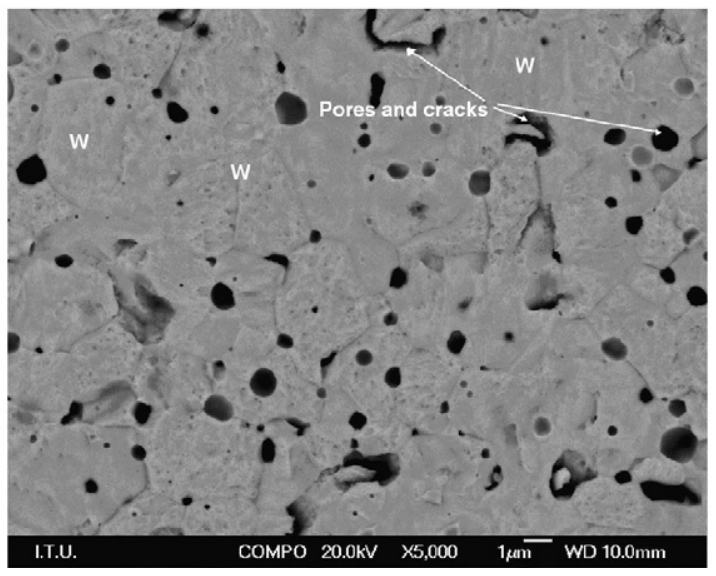

Fig. 8. (a), (b) and (c) SEM images of $3 \mathrm{~h}, 6 \mathrm{~h}$ and $24 \mathrm{~h} \mathrm{MA}$ 'd W20SiC samples sintered at $1770^{\circ} \mathrm{C}$.

(a)

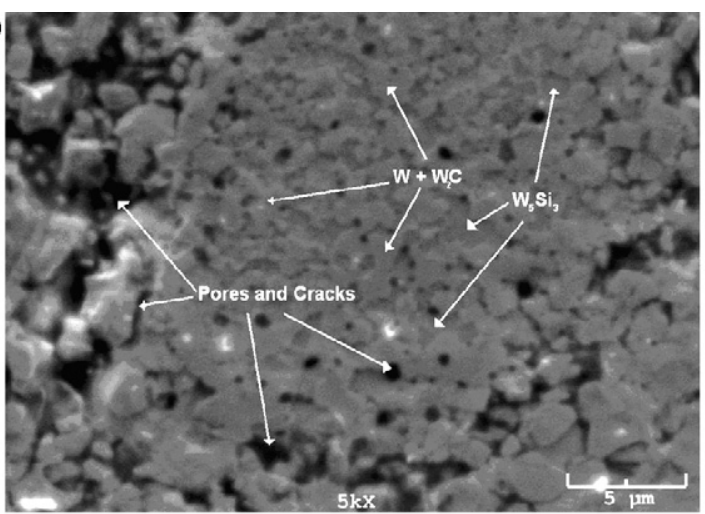

(b)

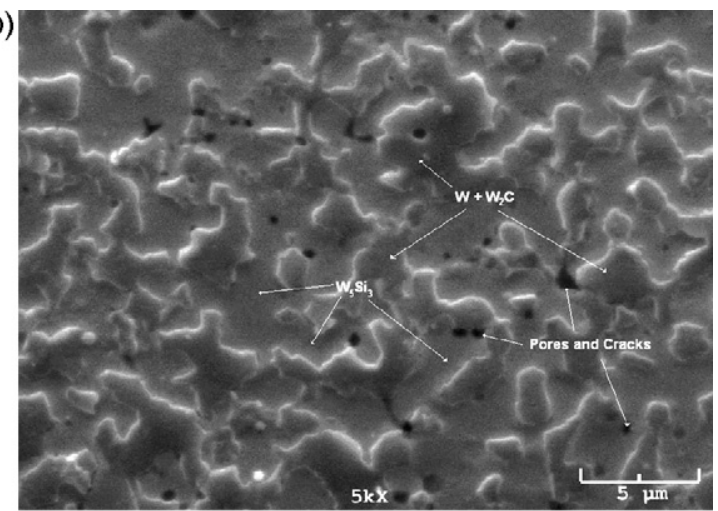

(c)

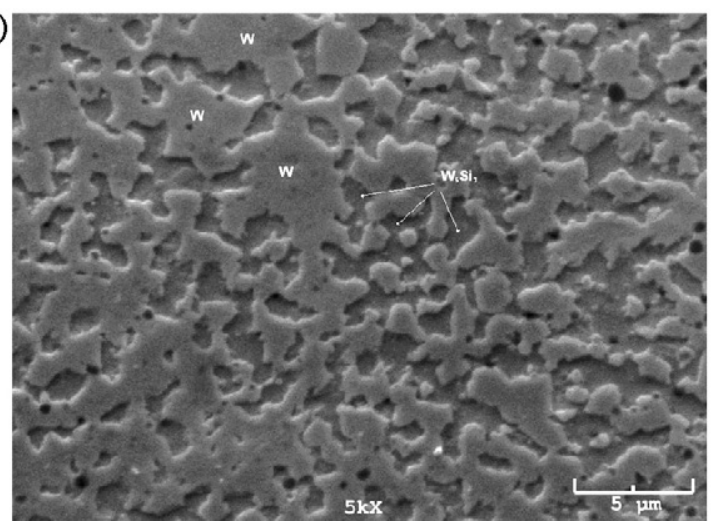

Fig. 9. (a), (b) and (c) SEM images of $3 \mathrm{~h}, 6 \mathrm{~h}$ and $24 \mathrm{~h}$ MA'd W20SiC samples sintered at $1680^{\circ} \mathrm{C}$, respectively. 
Table 2

Bulk density $\left(\mathrm{g} / \mathrm{cm}^{3}\right)$ and relative density (\%) values of W20SiC samples in the asconsolidated state and after sintering at $1680^{\circ} \mathrm{C}$ and at $1770^{\circ} \mathrm{C}$.

\begin{tabular}{lrrr}
\hline & \multicolumn{1}{c}{ 3 h MA'd } & \multicolumn{1}{c}{ 6h MA'd } & \multicolumn{1}{c}{ 24h MA'd } \\
\hline As-consolidated & $8.67(55.0 \%)$ & $8.62(54.0 \%)$ & $8.01(51.3 \%)$ \\
Sintered at $1680^{\circ} \mathrm{C}$ & $14.00(89.0 \%)$ & $14.60(93.0 \%)$ & $15.33(97.7 \%)$ \\
Sintered at $1770^{\circ} \mathrm{C}$ & $14.88(94.8 \%)$ & $15.03(95.8 \%)$ & $14.94(95.2 \%)$ \\
\hline
\end{tabular}

the brittle $\mathrm{W}_{2} \mathrm{C}$ phase in substantial amounts. Moreover, the distribution of the pores and cracks is non-uniform, which makes the microstructure inhomogeneous. On the other hand, the sintered sample MA'd for $6 \mathrm{~h}$ (Fig. 9b) has a more uniform microstructure with larger grains and smaller amount of pores than the $3 \mathrm{~h}$ MA'd sample. It can be observed that although the microstructures of W20SiC samples MA'd for $24 \mathrm{~h}$ (Fig. 9c) and MA'd for $6 \mathrm{~h}$ (Fig. 9b) are similar, the former is finer than the latter. Moreover, as detected in Fig. 7a and observed in Fig. 9b and c, while the $6 \mathrm{~h}$ MA'd sample contains the $\mathrm{W}_{2} \mathrm{C}$ phase in addition to the $\mathrm{W}$ and $\mathrm{W}_{5} \mathrm{Si}_{3}$ phases, $24 \mathrm{~h}$ MA'd sample has only two phases which are $\mathrm{W}$ and $\mathrm{W}_{5} \mathrm{Si}_{3}$ phases.

\subsubsection{Density measurements}

The results of the density measurements of both green compacts and sintered samples are given in Table 2 . The theoretical density of W20SiC samples is calculated as $15.7 \mathrm{~g} / \mathrm{cm}^{3}$. Relative densities of sintered samples changed with MA duration which varied from $89.0 \%$ to $97.7 \%$ for samples sintered at $1680^{\circ} \mathrm{C}$. On the other hand, those for W20SiC samples sintered using second sintering cycle are about $95 \%$. According to these results, it is clear that the bulk density increases with increasing sintering temperatures for the samples MA'd for $3 \mathrm{~h}$ and $6 \mathrm{~h}$ as a result of thermal activation and increased atom diffusivity (Fig. 10a). Noting the fact that relative density values of $92 \%$ and above are accepted as high sintering densities [20,21], relative sinter densities of about $95 \%$ achieved in this study for all W20SiC samples MA'd at different times $(3 \mathrm{~h}, 6 \mathrm{~h}$ and $24 \mathrm{~h}$ ) sintered using an upper and a lower sintering temperature (second sintering regime) are remarkable. Furthermore, sintering at $1680^{\circ} \mathrm{C}$ yields an almost perfect bulk density value of $97.7 \%$ for the W20SiC sample MA'd for $24 \mathrm{~h}$ which is the maximum sinter density value achieved in the present investigation. However, this is a result of a unique combination of sintering temperature and MA time. As seen in Table 2 and Fig. 10, bulk densities of the samples sintered at $1680^{\circ} \mathrm{C}$ drastically increases with increasing MA duration, viz. $89.0 \%, 93.0 \%$ and $97.7 \%$ for $3 \mathrm{~h}, 6 \mathrm{~h}$ and $24 \mathrm{~h}$, respectively. It is believed that two mechanisms contribute to the increase of bulk density with MA for the W20SiC samples sintered at $1680^{\circ} \mathrm{C}$. First of all, with increasing MA duration, mechanically activated sintering kinetics due to cold work stored energy enhances densification during sintering. Secondly, increasing MA duration causes more homogeneous distribution of $\mathrm{SiC}$ phase in the $\mathrm{W}$-matrix which contributes to higher sinter densities. On the other hand, the fact that an almost constant sintering density ( $\sim 95 \%)$ value is achieved for all W20SiC samples sintered using the second sintering regime could be attributed to slower sintering kinetics [22,23,33-35] due to the "frozen" microstructure as reported in the literature [22,23,31-35].

\subsubsection{Microhardness measurements}

Since the samples produced in this research were very small, only microhardness measurements were used to investigate mechanical behavior of the samples. Vickers microhardness results of sintered W20SiC samples are given in Fig. 11 and are tabulated in Table 3. As seen in both Fig. 11 and Table 3, with increasing MA duration, hardness values decreased for both sintering temperatures. It is quite evident that hardness increases with increasing amount of $\mathrm{W}_{2} \mathrm{C}$ in the $\mathrm{W}$-matrix of the sintered microstructure. Thus, for all sintered W20SiC samples using both sintering conditions, decrease
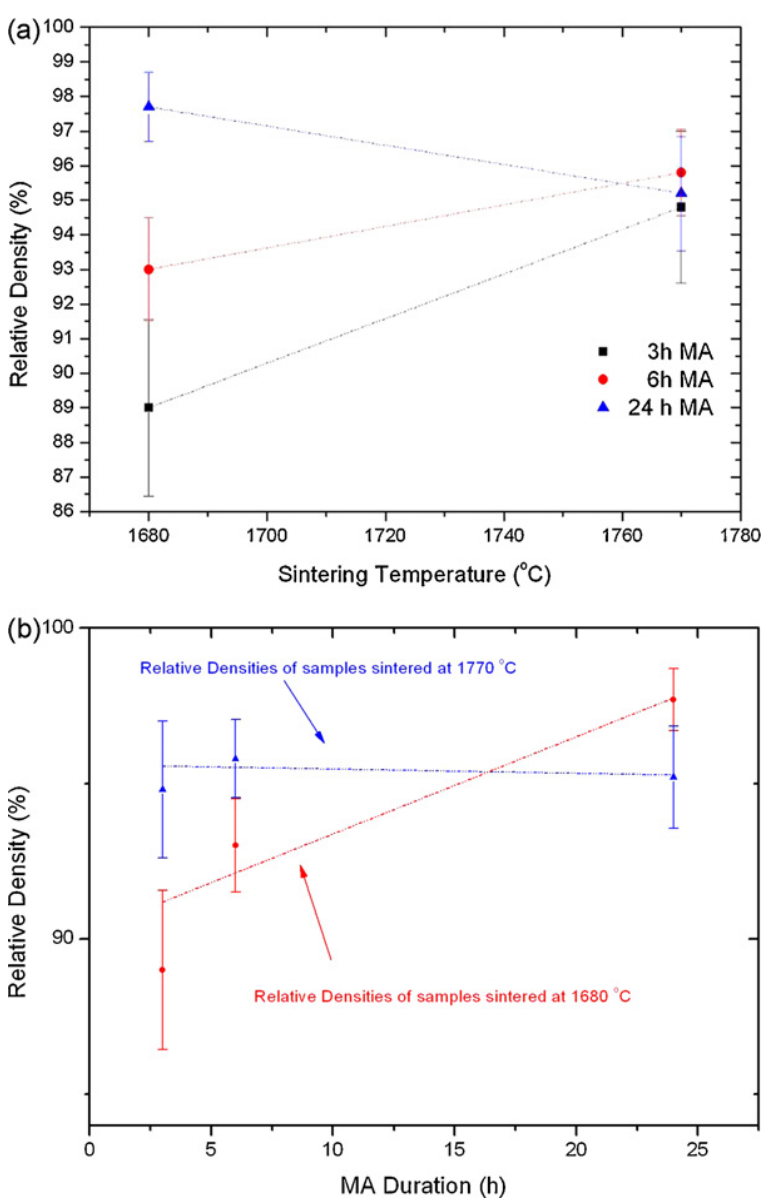

Fig. 10. (a) Relative density of W200SiC samples vs. sintering temperature and (b) relative density vs. amount of MA

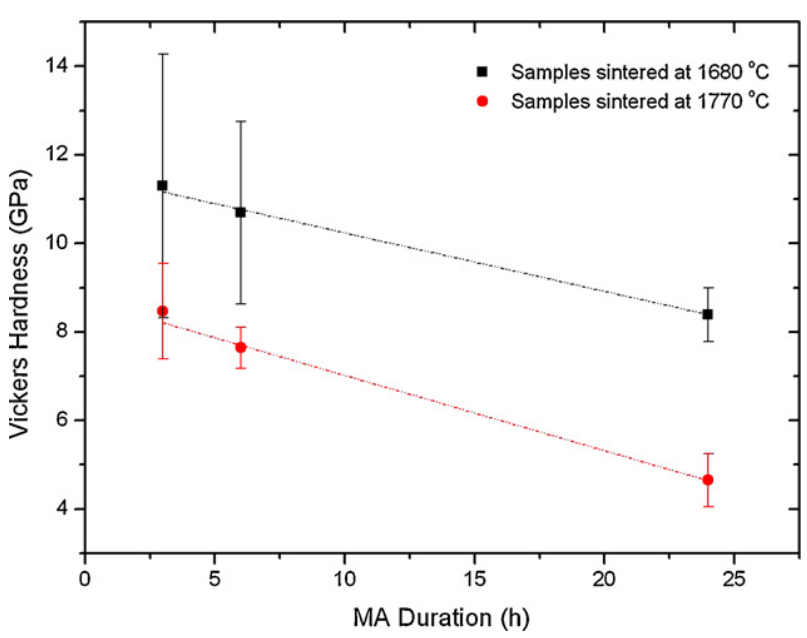

Fig. 11. Average microhardness values and standard deviations of W20SiC samples sintered at $1680^{\circ} \mathrm{C}$ and $1770^{\circ} \mathrm{C}$ as a function of MA time.

Table 3

Vickers microhardness results (GPa) of the W20SiC samples sintered at $1680^{\circ} \mathrm{C}$ and at $1770^{\circ} \mathrm{C}$

\begin{tabular}{lrrr}
\hline MA & \multicolumn{1}{l}{ 3h } & \multicolumn{1}{l}{ h } & \multicolumn{1}{l}{$24 \mathrm{~h}$} \\
\hline Sintered at $1680^{\circ} \mathrm{C}$ & $11.30 \pm 2.98$ & $10.69 \pm 2.06$ & $8.39 \pm 0.61$ \\
Sintered at $1770^{\circ} \mathrm{C}$ & $8.47 \pm 1.08$ & $7.64 \pm 0.47$ & $4.65 \pm 0.60$
\end{tabular}


in hardness values is due to decrease in the amount of $\mathrm{W}_{2} \mathrm{C}$ phase with increasing MA duration, as evidenced by XRD graphs given in Fig. 7. Considering the hardness values of the samples MA'd for $3 \mathrm{~h}$ and MA'd for $6 \mathrm{~h}$ sintered at $1680^{\circ} \mathrm{C}$, both have high hardness values (11.3 GPa for MA'd $3 \mathrm{~h}$ and $10.7 \mathrm{GPa}$ for MA'd $6 \mathrm{~h}$ ) and also have very high standard deviation values. From the SEM micrographs shown in Fig. 9, it can be observed that these high standard deviation values can be attributed to non-uniform nature of pore and crack distribution. High amount of $\mathrm{W}_{2} \mathrm{C}$ phase is the reason for both high hardness values and the presence of cracks and pores in W20SiC MA'd for $3 \mathrm{~h}$ and $6 \mathrm{~h}$ followed by sintering at $1680^{\circ} \mathrm{C}$. As expected, the sample MA'd for $24 \mathrm{~h}$ and sintered at $1680^{\circ} \mathrm{C}$ with no $\mathrm{W}_{2} \mathrm{C}$ phase has a lower microhardness value and a very low standard deviation as a result of its homogeneous microstructure. Hardness values of all W20SiC samples sintered using the second sintering regime were lower than those of sintered at $1680^{\circ} \mathrm{C}$, probably due to larger grain sizes achieved in the W20SiC samples sintered using the second sintering regime.

\section{Conclusions}

On the basis of the results of the present investigation, the following observations and conclusions can be drawn.

1. Only $\mathrm{W}$ phase with no other intermetallic phases has been identified in all MA'd W20SiC powders of the present investigation. Both average grain size and particle sizes of the MA'd powders decrease with MA duration. Average grain sizes, calculated on the basis of broadening of XRD peaks, have been predicted as $26 \mathrm{~nm}$ and $12 \mathrm{~nm}$ for W20SiC powders MA'd for $3 \mathrm{~h}$ and $6 \mathrm{~h}$, respectively. In addition, low particle sizes like $202 \mathrm{~nm}$ and $195 \mathrm{~nm}$ are obtained for W20SiC samples after MA for $6 \mathrm{~h}$ and $24 \mathrm{~h}$, respectively.

2. Using two different sintering regimes, $\mathrm{W}_{2} \mathrm{C}$ and $\mathrm{W}_{5} \mathrm{Si}_{3}$ phases have been identified in the $\mathrm{W}$-matrix for the sintered samples of W20SiC MA'd for $3 \mathrm{~h}$ and $6 \mathrm{~h}$ whereas $\mathrm{W}_{2} \mathrm{C}$ is not present for the ones MA'd for $24 \mathrm{~h}$. With increasing MA duration, the sintered microstructures become more homogeneous and pore-free.

3. Bulk densities of the samples sintered at $1680^{\circ} \mathrm{C}$ varies between $89.0 \%$ and $97.7 \%$ with the maximum value achieved after MA for $24 \mathrm{~h}$. On the other hand, constant relative sinter densities of about $95 \%$ are measured for all W20SiC samples MA'd at different times and sintered using an upper and a lower sintering temperature.

4. For all W20SiC composites sintered by two different sintering regimes, microhardness values decrease with increasing $M A$ duration as a result of $\mathrm{W}_{2} \mathrm{C}$ depletion with increasing MA duration. Of all sintered W20SiC samples, the one MA'd for $3 \mathrm{~h}$ and sintered at $1680^{\circ} \mathrm{C}$ has the maximum microhardness value of about $11.3 \mathrm{GPa}$.

In overall, the present investigation has shown that mechanical alloying is very effective in preparing the W20SiC composites with high relative densities $(\geq 95 \%)$ sintered at unconventionally low sintering temperatures $\left(1680^{\circ} \mathrm{C}\right.$ and $\left.1770^{\circ} \mathrm{C}\right)$.

\section{Acknowledgements}

The authors would like to thank Çiğdem Çakır for carrying out experiments in Jeol ${ }^{\mathrm{TM}}$-JSM-T330 scanning electron microscope (SEM), Hüseyin Sezer for carrying out experiments in Jeol ${ }^{\mathrm{TM}}$-JSM7000F field emission scanning electron microscope (SEM).
We also would like to acknowledge the Scientific and Technological Research Council of Turkey (TUBITAK) for funding the project entitled "Development of polymer composite and sinter products using tungsten based nanostructured and nanocomposite powders fabricated via mechanical alloying and mechanochemical techniques" with the project number 105M065.

Further, we would like to express our gratitude to State Planning Organization (DPT) for funding the project entitled "Advanced Technologies in Engineering" with the project number 2001 K120750 out of which the main infrastructure of the Particulate Materials Laboratories was founded.

\section{References}

[1] G.M. Song, Y.J. Wang, Y. Zhou, International Journal of Refractory Metals \& Hard Materials 21 (2003) 1-12.

[2] H.G. Tang, X.F. Ma, W. Zhao, X.W. Yan, J.M. Yan, C.J. Zhu, Solid State Communications 129 (2004) 147-150.

[3] S. Coskun, O. Meydanoglu, D. Tatar, T. Ozbek, E. Corduk, Building a boat using polymeric-composite materials, Graduation Project, I.T.U., Istanbul, 2004.

[4] N. Chawla, Y.L. Shen, Advanced Engineering Materials 3 (2001) 357-370.

[5] D.D.L. Chung, Applied Thermal Engineering 21 (2001) 1593-1605.

[6] G.M. Song, Y.J. Wang, Y. Zhou, Materials Science and Engineering A 334 (2002) $223-232$.

[7] K.H. Lee, J.K. Yoon, J.K. Lee, J.M. Doh, K.T. Hong, W.Y. Yoon, Surface \& Coatings Technology 187 (2004) 146-153.

[8] S. Coskun, Development and characterization investigations of mechanically alloyed $\mathrm{W}-\mathrm{SiC}$ and $\mathrm{W}-\mathrm{SiC}-\mathrm{Y}_{2} \mathrm{O}_{3}$ composites, M.Sc. Thesis, I.T.U., Istanbul, 2006.

[9] W. Rafaniello, M. Srinivasan, in: W.A. Weimer (Ed.), Carbide, Nitride, and Boride Materials Synthesis and Processing, Chapman-Hall, London, 1997.

[10] J. Marchi, J.C. Bressiani, A.H.A. Bressiani, Materials Research 4 (2001) 231-236.

[11] H.O Pierson, Handbook of Refractory Carbides and Nitrides Properties, Charac teristics, Processing and Applications, Noyes Publications, USA, 1996.

[12] H.J. Ryu, S.H. Hong, W.H. Baek, Materials Science and Engineering A 291 (2000) 91-96.

[13] C. Suryanarayana, E. Ivanov, V.V. Boldyrev, Materials Science and Engineering A 304-306 (2001) 151-158.

[14] C. Suryanarayana, Progress in Materials and Science 46 (2001) 1-184

[15] H.J. Fecht, in: C.C. Koch (Ed.), Nanostructured Materials: Processing, Properties and Potential Applications, Noyes Publications, New York, 2002.

[16] M.L. Öveçoğlu, Development of a dispersion-strengthened Al-Fe-Ce alloy by mechanical alloying and related theoretical modeling of dislocations in composite materials, PhD Thesis, Stanford University, Palo Alto, CA, 1987.

[17] J.S. Benjamin, Materials Science Forum 88-90 (1992) 1-18.

[18] C. Suryanarayana, M.G. Norton, X-Ray Diffraction: A Practical Approach, Plenum Press, New York, 1998

[19] Powder Diffraction Files: Card No. 04-0806, Database Edition, Joint Committee on Powder Diffraction Standards (JCPDS), Newton Square, PA, USA, 2006.

[20] F.R. Cheney, in: E. Klar (Ed.), Metals Handbook, vol. 7, ASM, 1984.

[21] A. Belhadjamida, R.M. German, in: A. Crowson, E.S. Chen (Eds.), Tungsten and Tungsten Alloys: Recent Advances, TMS, PA, USA, 1991.

[22] I.W. Chen, X.H. Wang, Nature 404 (2000) 168-171.

[23] I.W. Chen, Low temperature processing and kinetics of ceramics and ceramic matrix composites with large interfacial areas, Department of Energy, Basic Energy Sciences, Final Technical Report, Philadelphia, USA, 2000.

[24] Powder Diffraction Files: Card No. 35-0776, Database Edition, Joint Committee on Powder Diffraction Standards (JCPDS), Newton Square, PA, USA, 2006.

[25] Powder Diffraction Files: Card No. 51-0941, Database Edition, Joint Committee on Powder Diffraction Standards (JCPDS), Newton Square, PA, USA, 2006.

[26] W.F. Seng, P.A. Barnes, Materials Science and Engineering B 72 (2000) 13-18.

[27] L. Baud, C. Jaussaud, R. Madar, C. Bernard, J.S. Chen, M.A. Nicolet, Materials Science and Engineering B 29 (1995) 126-130.

[28] S.J. Son, K.H. Park, Y. Katoh, A. Kohyama, Journal of Nuclear Materials 329-333 (2004) 1549-1552.

[29] F. Goesmann, R. Schmid-Fetzer, Materials Science and Engineering B 46 (1997) 357-362.

[30] F. Goesmann, R. Schmid-Fetzer, Materials Science and Engineering B 34 (1995) 224-231.

[31] C.L. Robert, F. Ansart, C. Deloget, M. Gaudon, A. Rousset, Ceramics International 29 (2003) 151-158.

[32] X.H. Wang, P.L. Chen, I.W. Chen, Journal of the American Ceramic Society 89 (2) (2006) 431-437.

[33] H.T. Kim, Y.H. Han, Ceramics International 30 (2004) 1719-1723.

[34] S.H. Lee, Ceramics International 30 (2004) 579-584.

[35] L.B. Kong, J. Ma, W. Zhu, O.K. Tan, Materials Research Bulletin 36 (2001) $1675-1685$. 